\title{
Biotic and Abiotic Constraints on the Decomposition of Fagus sylvatica Leaf Litter Along an Altitudinal Gradient in Contrasting Land-Use Types
}

\author{
Konstantin Gavazov, ${ }^{1,2 *}$ Robert Mills, ${ }^{1,2}$ Thomas Spiegelberger, ${ }^{1,3}$ \\ Jonathan Lenglet, ${ }^{1,2}$ and Alexandre Buttler ${ }^{1,2,4}$
}

\begin{abstract}
${ }^{1}$ School of Architecture, Civil and Environmental Engineering ENAC, Laboratory of Ecological Systems ECOS, Ecole Polytechnique Fédérale de Lausanne EPFL, Station 2, 1015 Lausanne, Switzerland; ${ }^{2}$ Swiss Federal Institute for Forest, Snow and Landscape Research WSL, Site Lausanne, Station 2, 1015 Lausanne, Switzerland; ${ }^{3}$ UR EMGR Mountain Ecosystems, Irstea, 2 Rue Papeterie, BP 76, 38402 Saint-Martin d'Hères, France; ${ }^{4}$ University of Franche-Comté- CNRS, UMR 6249 Chrono-environnement, 16 Route de Gray, 25030 Besançon Cedex, France
\end{abstract}

\begin{abstract}
Climate change can affect the process of carbon cycling and leaf litter decomposition in multiple ways, both directly and indirectly, though the strength and direction of this relationship is often context dependent. In this experiment, we followed decomposition of a standard litter type-senescent leaves of Fagus sylvatica collected from a single location-along a $1000 \mathrm{~m}$ altitudinal gradient of four sites over 2.5 years. To control the edaphic conditions, we transplanted intact turf mesocosms from three different land-use types
\end{abstract}

Received 26 November 2013; accepted 5 June 2014; published online 19 July 2014

Electronic supplementary material: The online version of this article (doi:10.1007/s10021-014-9798-9) contains supplementary material, which is available to authorized users.

Author contributions KG, TS, and AB designed the study, KG and JL collected field data and performed laboratory analyses. KG analyzed data and wrote the manuscript with contributions from RM, TS, and AB.

*Corresponding author; e-mail: konstantin.gavazov@epfl.ch [densely wooded, sparsely wooded, and unwooded (UW) pastures] from the highest altitude site into UW pastures along the altitudinal gradient from the moist, cool high-elevation site to the dry, warm low-elevation site, using shade cloth to mimic the light conditions in the original habitats. Decomposition in the drier UW pasture mesocosms increased with altitude, likely because of higher moisture at the highest sites. Decomposition in the more mesic mesocosms from sparsely and densely wooded sites was insensitive to altitude, suggesting an overriding moisture, rather than temperature, constraint on decomposition across these sites. The functional composition of decomposer microbial communities (fungal/bacterial ratio) was similarly insensitive to altitude. Our findings bring substantial evidence for the controlling role of soil moisture on litter decomposition, as well as for the indirect effects of climate through changes in the decomposer community.

Key words: beech; climate change; $\mathrm{C} / \mathrm{N}$ ratio; litter bag; litter decay rate $(\mathrm{K})$; fungal/bacterial ratio; JURA mountains; pasture-woodlands; PLFA; transplantation. 


\section{INTRODUCTION}

Litter and soil organic matter decomposition represent one of the major carbon fluxes from terrestrial ecosystems (Houghton 2007). Environmental conditions directly affect the rates of litter decomposition (Chapin and others 2002) such that in cold environments, such as mountain regions, ecosystems contain most of their carbon in the soil organic matter due to physiological constraints on the decomposer community (Körner 2003). In such cold biomes, temperature exerts a hierarchical control on litter decomposition, however, soil moisture modulates its direct positive effect, or even overrides it, based on regional precipitation and evapotranspiration regimes (Aerts 2006). In milder climates, litter quality is much more important for the rate of decomposition, especially during the initial stage of mass loss when labile substances are released (Couteaux and others 1995), but also during the subsequent degradation of recalcitrant material by filtering the composition of microbial communities (Bray and others 2012). This demonstrates how climate can also have indirect effects on decomposition mediated by a change in vegetation or in its litter quality (Cornelissen and others 2007; Cornwell and others 2008), but also by vegetation's feedback on soil microclimate (Körner 2003). Concomitant climatedriven changes in the soil microbial communities also affect the carbon cycle (Bardgett and others 2013) and litter decomposition in particular (Allison and others 2013), thus exerting another indirect climate effect.

In a changing climate (Solomon and others 2007), where mountain systems are said to experience a disproportionately higher increase in temperature (Nogues-Bravo and others 2007), the coupling between atmospheric and soil climatic conditions (Seneviratne and others 2006) can induce positive climate change feedbacks with far reaching implications for future terrestrial carbon cycling and litter decomposition. Reports on the confounding effect of soil moisture in climate warming experiments on litter decomposition come from a range of studies in both high latitude (Robinson 2002) and high altitude (Gavazov 2010) regions. These studies suggest a link to a documented strong moisture limitation of underlying metabolic processes in the soil (Steinweg and others 2012). As soil moisture is an essential control of $\mathrm{C}$ turnover and co-varies with changing temperature (Mueller and Seneviratne 2012), it is important to assess the impact of these environmental parameters on litter decomposition in concert.
Altitudinal gradient studies represent a natural approach to evaluate the impact of climatic parameters on ecological processes (Körner 2007). In particular, transplantation studies along climatic gradients present great potential for integrating ecosystem-scale climate change manipulations with natural environmental variation along substantial temporal and spatial scales (Beier and others 2012). They grant the possibility of mapping the response of an ecological process to a large range of variation in a given environmental parameter of interest (that is, temperature, precipitation, and so on), while controlling for the effect of others (that is, substrate, edaphic factors), establishing a causal relationship through a statistical regression approach (Cottingham and others 2005).

In this study we present data on decomposition rates of a standard litter type-senesced leaves of European beech Fagus sylvatica-along an altitudinal gradient of approximately $1000 \mathrm{~m}$ spanning from the subalpine (wet and cold) to the colline (dry and warm) vegetation zones in the Swiss Jura Mountains (Figure 1A). To standardize the edaphic conditions along the gradient, prior to litter bag incubation in the field, four common gardens were set up at distinct elevations, in which we transplanted intact turf mesocosms from three different land-use types (see Table 1) originating from an area of mosaic pasturewoodlands at the crest of the Jura Mountains. Alongside mass loss and chemical composition of the decaying litter, we monitored the temporal dynamics of the decomposer microbial community. Based on the climatic gradient used, we hypothesized that beech litter decomposition rates will be most rapid within an optimum climatic range at mid-altitude and experience soil moisture limitation at lower altitude and temperature limitation at higher altitude (Figure 1B). Distinct trajectories were expected for the three land-use types, such that at the top of the gradient unwooded (UW) pastures, characterized by rich grassland communities, would provide better conditions for litter decomposition in terms of a warmer microclimate, and a microbial community adapted to a faster soil organic matter cycle. However, at the bottom of the gradient, the pattern will be reversed since wooded pastures will experience less soil moisture limitation due to their canopy shading.

\section{Materials AND Methods}

\section{Experimental Design and Litter Bag Preparation}

The study was conducted within an existing turf-transplantation experiment at four distinct 

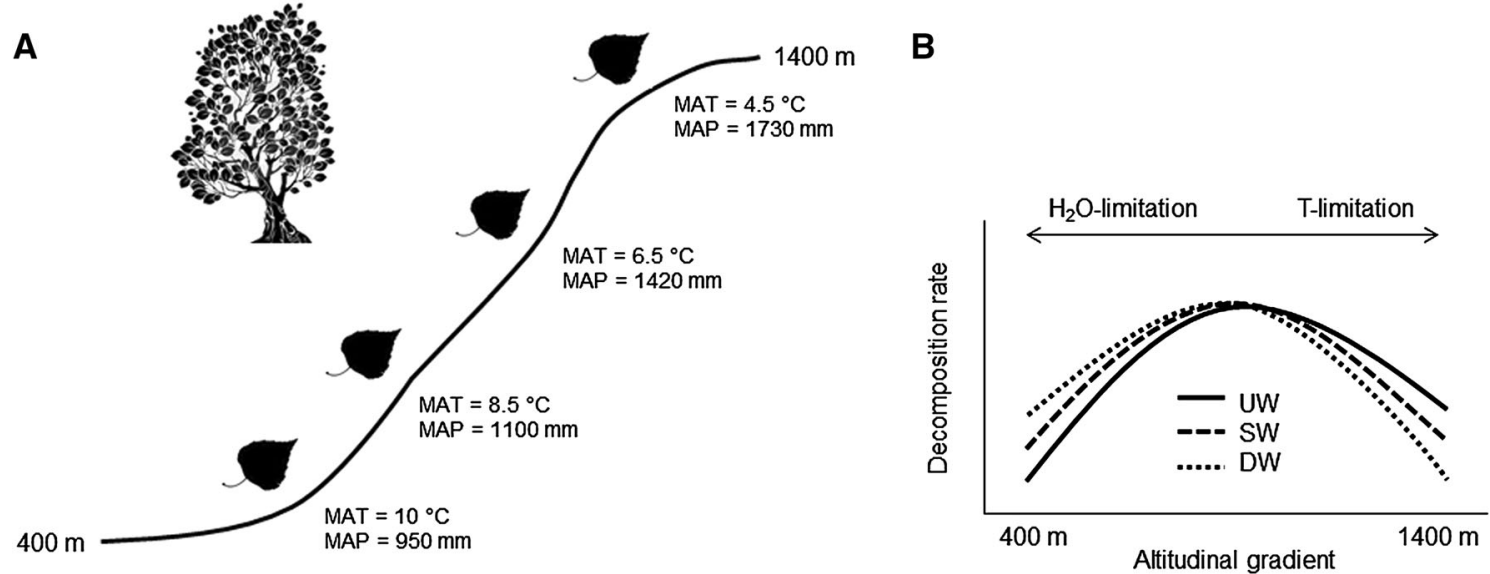

Figure 1. A Schematic representation of the altitudinal gradient used in this study and the corresponding climate experienced by litter bags with Fagus sylvatica leaves incubated on the surface of transplanted mesocosms. B A conceptual chart demonstrating the hypothetical controlling role of soil moisture and soil temperature on the litter decomposition process in each of the three studied land-use types: unwooded pasture (UW), sparsely wooded pasture (SW), and densely wooded pasture (DW).

Table 1. Biogeochemical Characteristics of the Topsoil Layer $(0$ to $-10 \mathrm{~cm})$ at the Control Site at $1350 \mathrm{~m}$ a.s.l

\begin{tabular}{lccc}
\hline Land use type $^{\mathrm{l}}$ & UW & SW & DW \\
\hline Bulk density $\left(\mathrm{g} / \mathrm{cm}^{3}\right)$ & $0.57 \pm 0.01$ & $0.54 \pm 0.04$ & $0.55 \pm 0.02$ \\
$\mathrm{pH}$ in $\mathrm{H}_{2} \mathrm{O}$ & $5.88 \pm 0.06$ & $5.47 \pm 0.15$ & $5.85 \pm 0.08$ \\
$\mathrm{SOM}(\mathrm{g} / \mathrm{g}$ dry soil) & $0.20 \pm 0.01$ & $0.18 \pm 0.01$ & $0.20 \pm 0.01$ \\
$\mathrm{C} / \mathrm{N}$ ratio & $15.90 \pm 0.57$ & $18.83 \pm 0.62$ & $20.25 \pm 0.42$ \\
Soil PLFA fungal/bacterial ratio & 0.200 & 0.217 & 0.350 \\
Mean annual soil temperature $\left({ }^{\circ} \mathrm{C}\right)$ & $6.58 \pm 0.15$ & $6.07 \pm 0.16$ & $5.70 \pm 0.11$ \\
Mean annual soil moisture $(\%)$ & $42.3 \pm 3.6$ & $37.6 \pm 2.9$ & $28.8 \pm 2.5$
\end{tabular}

${ }^{1}$ Land-use type codes, where UW refers to unwooded pasture with $0 \%$ canopy shading, SW refers to sparsely wooded pasture with $40 \%$ canopy shading, and DW refers to densely wooded pasture with $80 \%$ canopy shading.

altitudes simulating effects of climate change on pasture woodlands in the Swiss Jura Mountains (see Gavazov and others 2014). We used this gradient as a proxy for different in situ climatic conditions as represented in Figure 1A. Briefly, at each given altitude: $1350 \mathrm{~m}$ a.s.l. (Combe des Amburnex, $\mathrm{N} 46^{\circ} 54^{\prime}, \mathrm{E} 6^{\circ} 23^{\prime}$ ), $1010 \mathrm{~m}$ a.s.l. (Saint-George, N $46^{\circ} 52^{\prime}$, E $6^{\circ} 26^{\prime}$ ), $570 \mathrm{~m}$ a.s.l., (Arboretum d'Aubonne, $\mathrm{N} 46^{\circ} 51^{\prime}, \mathrm{E} 6^{\circ} 37^{\prime}$ ), and $395 \mathrm{~m}$ a.s.l. (Les Bois Chamblard, N $46^{\circ} 47^{\prime}, \mathrm{E} 6^{\circ} 41^{\prime}$ ), a common garden was set up within an open field with individual mesocosms. Those were made of rectangular PVC boxes $60 \times 80 \mathrm{~cm}$ and $35 \mathrm{~cm}$ in height, fitted with a drainage system (that is, a lysimeter), and dug down to soil surface level, thus preventing lateral heat exchange with the atmosphere. The intact turf monoliths for each mesocosm were translocated from the donor site at Combe des Amburnex ( $\mathrm{N}$ $46^{\circ} 55^{\prime}$, E $\left.6^{\circ} 24^{\prime}\right)$ - a mosaic area of subalpine pasture-woodlands situated along the crest of the Swiss Jura Mountains, at circa 1350 m a.s.l. The landscape there is dominated by Norway spruce Picea abies and beech $F$. sylvatica interspersed by large clearings for cattle pastures, where more intensive land-use management and grazing pressure keep ecosystem succession in check. Fifteen mesocosms were transplanted at each of the elevations: 1350, 1010, and $570 \mathrm{~m}$ a.s.l. with five replicates coming from each of the following three land-use types representing a gradient of land-use intensity, respectively, grazing activities: a densely wooded pasture (DW) with $80 \%$ light interception by the canopy and a typical understory of woody plants and forbs, a sparsely wooded pasture (SW) with $40 \%$ light interception and a rich community of mountain forbs and feather mosses, and an UW pasture 
without light interception and a subalpine grassland community. The respective donor sites were situated within $1 \mathrm{~km}$ of each other, each measured about $2 \mathrm{ha}$, and all shared the same geomorphology, microtopography, and aspect. Prior to the transplantation, the solar radiation field conditions in each land-use type were logged (PYR sensors, Decagon Devices, Inc., USA) over an entire growing season and subsequently simulated at each common garden site by two types of UV-resistant meshed roofs (that is, 40 and $80 \%$ shading) suspended over wooden frames at $50 \mathrm{~cm}$ above the surface of the mesocosms. The latter did not intercept rain precipitation and were taken off during winter to avoid interference with the snowpack. Due to logistical limitations, only five mesocosms of an UW pasture type were transplanted to $395 \mathrm{~m}$ a.s.l. Details of edaphic characteristics for each land-use type are given in Table 1.

Each mesocosm was equipped with a set of $\mathrm{ECH}_{2} \mathrm{O}$ EC-TM sensor probes coupled to Em50 data-loggers (Decagon Devices, Inc., USA) recording soil temperature and volumetric water content in top-soil $(0$ to $-3 \mathrm{~cm})$ every minute and averaging data over $1 \mathrm{~h}$ intervals. In addition, at each experimental site an automated weather station (Sensor Scope Sàrl, Switzerland) measured rain precipitation and air temperature and humidity $2 \mathrm{~m}$ above the ground surface at $1 \mathrm{~min}$ intervals.

The decomposition rate along the gradient was evaluated using the litter bag technique (Crossley and Hoglund 1962) and standard leaf litter of European beech $F$. sylvatica. Beech is a common deciduous tree species in European forests and its distribution in Swiss mountains ranges between 400 and $1400 \mathrm{~m}$ a.s.l. (Weber and others 2010). We used naturally senesced and shed leaves which were intercepted with meshes suspended at about $1 \mathrm{~m}$ above the forest floor within a homogeneous, mature beech stand situated at $580 \mathrm{~m}$ a.s.l. in the Arboretum National d'Aubonne N 46 $51^{\prime}$, E $6^{\circ} 37^{\prime}$. Leaves were collected in October 2009 without bias toward size, shape or color, and petioles were considered part of the leaf. Following air drying at $20^{\circ} \mathrm{C}$ until constant weight was reached, approximately $1.5 \mathrm{~g}$ litter was enclosed in UV-resistant polypropylene litterbags $(10 \times 10 \mathrm{~cm})$ of $5-\mathrm{mm}$ mesh size, and the mass of each bag was recorded. A double layer mesh was used for the bottom of the bags to limit the loss of fragmented litter, but still allowing for the access of macroarthropodes and earthworms (Cornelissen 1996). Subsamples were taken for establishing the initial chemical (carbon and nitrogen) composition and the gravimetric water content of the litter.
Litter bags were incubated on top of the soil after parting the extant vegetation and fixed in place by means of small plastic pegs, one in each corner of the bag. Five individual litter bags were placed in each plot in November 2009 and then collected sequentially in spring 2010, autumn 2010, spring 2011, autumn 2011, and spring 2012. To reflect the difference in winter season length at each altitude, spring sampling took place shortly after snowmelt and the flowering of Crocus albiflorus in the mesocosms. Both autumn samplings took place in early October with the onset of vegetation senescence.

\section{Litter Mass-Loss, Chemical, and PLFA Analyses}

Collected litterbag samples were brushed of adherent soil and subsequently lyophilized in a freeze drier (CHRIST Beta 2-8 LD plus, Germany) and weighed to determine their dry weight. Litter decomposition was expressed as percentage of initial dry mass-loss over time. A subsample of coarsely fragmented litter was taken for phospholipid fatty acid (PLFA) analysis and the rest of the sample was ground in a ball mill (Retsch MM200, Germany) for estimation of carbon and nitrogen content in an elemental analyzer (Carlo ErbaCNS-O 1108 , Italy).

Total microbial biomass, fungal, and bacterial biomass were determined using PLFA biomarkers. The analysis followed the protocol of White and others (1979) with modifications as in Andersen and others (2010). In brief, lipids from $300 \pm 1 \mathrm{mg}$ of lyophilized litter were dissolved in a 1:2:0.8 solution of chloroform, methanol, and potassium phosphate buffer and shaken for $2 \mathrm{~h}$. Equal volumes of chloroform and buffer were then added and the two phases were left to separate overnight. The chloroform phase was reduced by $\mathrm{N}_{2}$ evaporation and the lipids were then split into neutral, glyco-, and phospholipids with silica solid phase extraction cartridges by eluting sequentially with chloroform, acetone, and methanol. The phospholipids were then trans-esterified in fatty acid methyl esters (FAMEs), evaporated under oxygen-free $\mathrm{N}_{2}$, and re-suspended in $1 \mathrm{ml}$ hexane containing $100 \mu \mathrm{l}$ of methyl nonadecanoate (19:0) (SigmaAldrich, Switzerland) as an internal standard. FAMEs were subsequently identified by retention time in a gas chromatograph (Varian Inc. CP3800, USA) with reference to commercial standards including bacterial and fungal acid methyl esters (Supelco, USA).

We used PLFAs i15:0, a 15:0,15:0, i16:0, 16:1 $\omega 7 \mathrm{c}$, i17:0, cyl7:0, 17:0, and cyl9 as markers for 


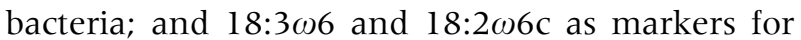
fungi (Bardgett and others 1996; Wilkinson and others 2002). Following de Vries and others (2012), we used the sum of all these biomarkers as an indicator of microbial community size and the ratio between fungal and bacterial biomarkers as an indicator of microbial community structure.

\section{Statistical Analysis}

Each response variable of interest (daily soil temperature and moisture, remaining litter mass, litter chemistry, amount, and composition of microbial PLFA) was tested in a mixed effects model for the effect of land use as a categorical variable, altitude as a continuous covariate, and sampling date as a repeated measure, as well as their two- and three-way interactions. We used a maximized restricted log-likelihood (REML) procedure (Pinheiro and others 2012) to account for the unbalanced structure of our dataset, that is, four altitudes in the case of UW land-use type, as opposed to three. As a general rule (Green and Tukey 1960), non-significant interaction terms with $F$ values $<2$ were pooled with the error term. To elucidate significant interactions with land use, the effects of altitude and sampling date were furthermore tested within each land-use type using the same model structure (Engqvist 2005). In addition, linear regression models were employed to establish the effects of atmospheric climate (mean daily values for air temperature, air humidity, and precipitation) on the respective soil microclimate (soil temperature and moisture) within the transplanted mesocosms.

For each mesocosm, mean values of soil temperature and moisture between two sampling dates were used as representative of the microclimate experienced by litter bags during each incubation period. Their effect on the litter mass loss between successive sampling dates was tested in a similar mixed effect model as described above, using them as continuous covariates. Because all sampling dates tightly followed the winter and summer seasons, we tested the effect of sampling date (that is, first winter, first growing season, second winter, second growing season, and third winter) on the sequential litter mass loss, using sampling date as a categorical variable. Similarly, the sampling dates were grouped into two categories-winter and growing season-to compare the corresponding mass loss in those two contrasting periods.

Comparison of litter decay rates among the different altitude and land-use treatments was done using the decomposition rate constant ( $K$ value) from a negative exponential model: $M_{\mathrm{t}}=M_{0} \mathrm{e}^{-k t}$ (Olson 1963), where $M_{\mathrm{t}}$ is the mass in litter bags at a given sampling date, $M_{0}$ is the initial mass in litterbags, and $t$ is the incubation period in years. Individual models were fit to the five sampling dates within each plot and solved for $k$. The resulting $K$ values were tested in an analysis of covariance for the effects of land use, altitude, and their two way interaction. Based on our hypothesis for an optimum climatic range for decomposition at mid-elevation, altitude was specified in the model both as linear and quadratic terms. As above, upon detection of a significant interaction, the effect of altitude was determined within each landuse type separately; and that of land use - within each altitude along the gradient.

Assumptions of normality and homoscedasticity of the residuals in all linear regression models were verified visually using diagnostic plots and effects were considered significant at $P<0.05$. All statistical analyses were performed in R 2.15.1, using the package 'nlme' (Pinheiro and others 2012).

\section{RESUlts \\ Climatic Gradient}

Microclimatic conditions in the transplanted mesocosms varied significantly over the 2.5 year decomposition period (Figure 2). Turf transplantation to lower altitude resulted in a significant increase in soil temperature $\left(F_{1,44}=262.2, P<0.001\right)$ and a concomitant decrease in soil moisture $\left(F_{1,44}=30.0\right.$, $P<0.001)$. Turfs from the contrasting land-use types were overall warmer $\left(F_{2,44}=9.6, P<0.001\right)$ and wetter $\left(F_{1,44}=30.0, P<0.001\right)$ with decreasing canopy shading in the order DW $<\mathrm{SW}<\mathrm{UW}$ pastures (Table 1). The observed gradient in soil surface temperature in the mesocosms was mainly due to variation in the air temperature along the altitudinal transect (linear regression $R^{2}=0.77$, $P<0.001)$, with the small part of unexplained variation coming from the winter periods when snow covered soils remained decoupled from atmospheric temperature fluctuations. Soil moisture, however, was not directly influenced by any of the measured climatic variables (air temperature, air humidity, and precipitation) and showed a significant decrease at lower altitude $\left(F_{1,18}=48.5\right.$, $P<0.001$ ) only for the UW pasture land use, but not for the other two wooded pasture types (Figure 2).

\section{Litter Decomposition Rates and Mass Loss}

Overall, the remaining mass in the litterbags decreased significantly at higher altitude $\left(F_{1,44}=40.4\right.$, $P<0.001$ ) and was significantly less (up to $50 \%$ 


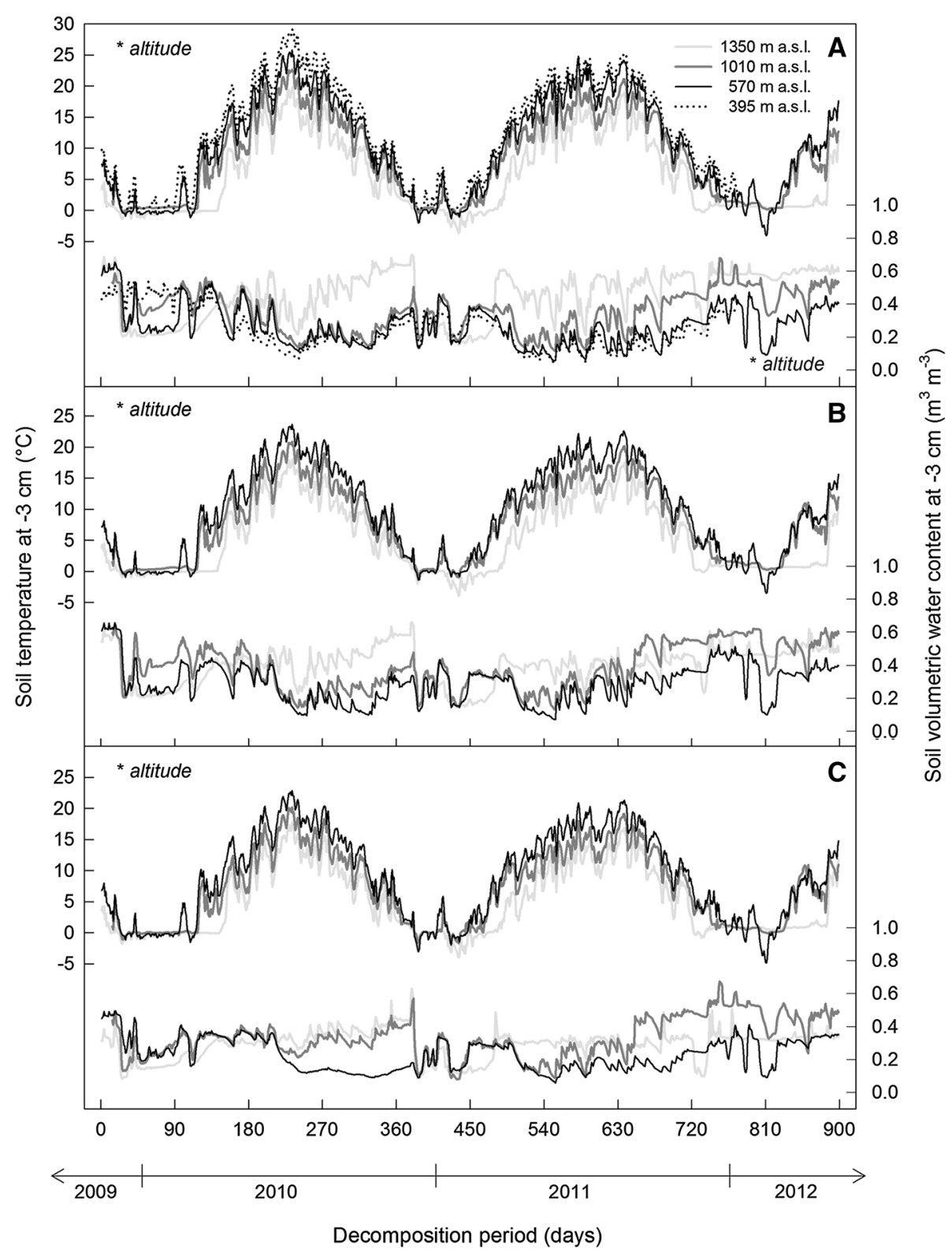

Figure 2. Soil microclimate in the transplanted mesocosms with turfs from: A unwooded pasture, B sparsely wooded pasture, and $\mathbf{C}$ densely wooded pasture land-use type, during the course of the 2.5 year long litter decomposition experiment. Presented are mean daily values for five replicate mesocosms. At the lowest altitude only the unwooded pasture land use was considered. Asterisks indicate significant effects of the specified factors within each of the land-use types.

mass loss after 2.5 years) in the UW pasture land use $\left(F_{2,44}=8.5, P<0.001\right)$. Nevertheless, as seen in Figure 3, exclusively the UW pastures experienced distinct rates of mass loss $\left(F_{1,18}=44.6, P<0.001\right)$ with respect to altitude, which was reflected by a significant altitude:land-use interaction $\left(F_{2,44}=7.9\right.$, $P=0.001)$. Mean soil moisture between two successive sampling dates had a significant effect on the sequential mass loss of litter $\left(F_{1,161}=5.4, P=0.021\right)$, but soil temperature had none. Mass loss was comparable between individual sampling dates and no apparent effect of winter or growing season periods was observed either.

All the estimated decay constants ( $K$ values) came from significant exponential models with
$84 \%$ of the $R^{2}$ values within the range $0.8-1.0$, and no $R^{2}$ values below 0.6. Similar to the mass loss analysis, the decomposition rates exhibited strong altitudinal $\left(F_{1,43}=14.6, P<0.001\right)$ and land use $\left(F_{2,43}=7.8, P=0.001\right)$ patterns, with a significant interaction between these two factors $\left(F_{2,43}=8.0\right.$, $P=0.001)$. Figure 4 shows that decomposition was positively affected by altitude only within the UW pasture type and this effect was linear $\left(F_{1,18}=25.5\right.$, $P<0.001)$. The rates of litter decomposition in the other two wooded land-use types did not vary along the altitudinal gradient, and they exhibited lower decomposition rates than UW at both $1350 \mathrm{~m}$ a.s.l. $\left(F_{2,12}=6.9, P=0.010\right)$ and $1010 \mathrm{~m}$ a.s.l. $\left(F_{2,12}=6.9, P=0.011\right)$. 


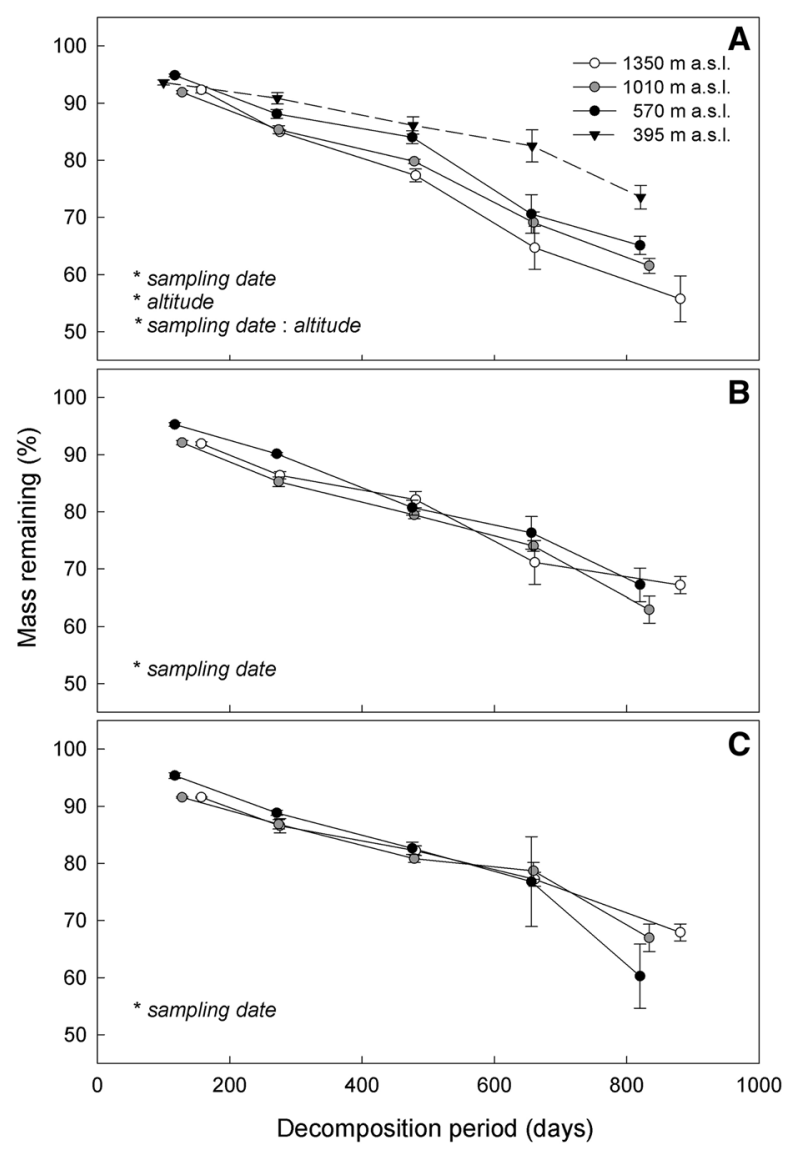

Figure 3. Percentage of initial mass remaining in the litter bags bi-annual sampling intervals, following their incubation in autumn 2009 on the surface of mesocosms from: A unwooded pasture, B sparsely wooded pasture, and $\mathbf{C}$ densely wooded pasture land-use type. Presented are mean values and standard errors for litterbags from five replicate mesocosms. At the lowest altitude only the unwooded pasture land use was considered. Asterisks indicate significant effects of the specified factors within each of the land-use types.

\section{Litter Chemistry}

Overall, the initial stoichiometric ratio of carbon and nitrogen $(\mathrm{C} / \mathrm{N}$ ratio $=71.3)$ decreased substantially over the course of litter decomposition (sampling date: $F_{1,196}=605.2, P<0.001$ ), and was largely influenced by the altitude of litter bag incubation $\left(F_{1,46}=64.6, P<0.001\right)$ and the land use $\left(F_{2,46}=3.9, P=0.027\right)$. Figure 5 shows that litter at lower altitudes had a consistently lower $\mathrm{C} / \mathrm{N}$ ratio across all three land-use types, however, the decrease was most pronounced at the UW pasture land use. When investigated separately, carbon and nitrogen contents revealed that a pulse increase of $+40 \%$ in nitrogen concentration after the first year of incubation and a steady one

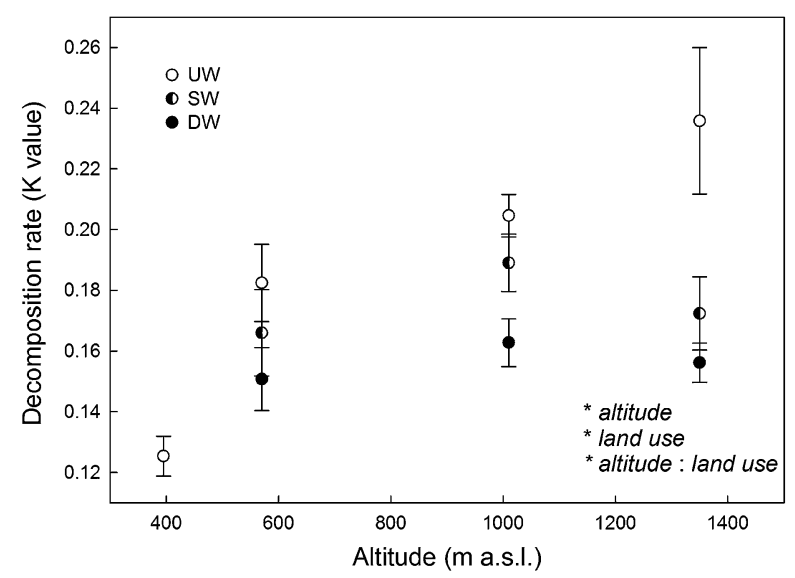

Figure 4. Leaf litter decomposition rates ( $K$ values) of Fagus sylvatica along an altitudinal gradient with mesocosms from three land-use types: unwooded pasture (UW) with $0 \%$ canopy shading, sparsely wooded pasture (SW) with 40\% canopy shading, and densely wooded pasture (DW) with $80 \%$ canopy shading. Presented are mean values and standard errors for five replicate plots. At the lowest altitude only the unwooded pasture land use was considered. Asterisks indicate significant effects of the specified factors.

thereafter (sampling date: $F_{1,196}=992.4, P<0.001$ ) was responsible for this change (see also Supplementary Material, Figure Al). This pattern was most expressed at lower altitude $\left(F_{1,46}=75.7, P<0.001\right)$.

\section{Microbial Community Composition}

The microbial communities on decomposing litter, assessed by the sum of the PLFA markers for fungi and bacteria, grew steadily over the course of the experiment (sampling date: $F_{1,198}=179.7, P<$ 0.001 ) without a significant land use effect (Figure 6). Only those litter bags incubated in UW pasture mesocosms revealed an altitude effect $\left(F_{1,18}=7.6\right.$, $P=0.013$ ), which, however, varied significantly in its direction over time (sampling date :altitude $F_{1,78}=4.0, P=0.049$ ) causing either an increase or a decrease in the total amount of PLFAs at a given sampling date.

A seasonal variation in fungal/bacterial ratio was evident too (Figure 7), with a significant overall effect of sampling date $\left(F_{1,197}=66.7, P<0.001\right)$. The magnitude of the altitude:sampling-date interaction $\left(F_{1,197}=8.75, \quad P=0.004\right)$ decreased along the UW-DW pasture gradient and so did the effect of altitude per se. Indeed, as in the case of total microbial PLFA, the variation in fungal/bacterial ratio in the litter bags was only influenced by altitude within the UW pasture mesocosms $\left(F_{1,18}=13.2, P=0.002\right)$. Overall, the altitude treatment caused a significant increase in bacterial PLFA markers at lower altitude 


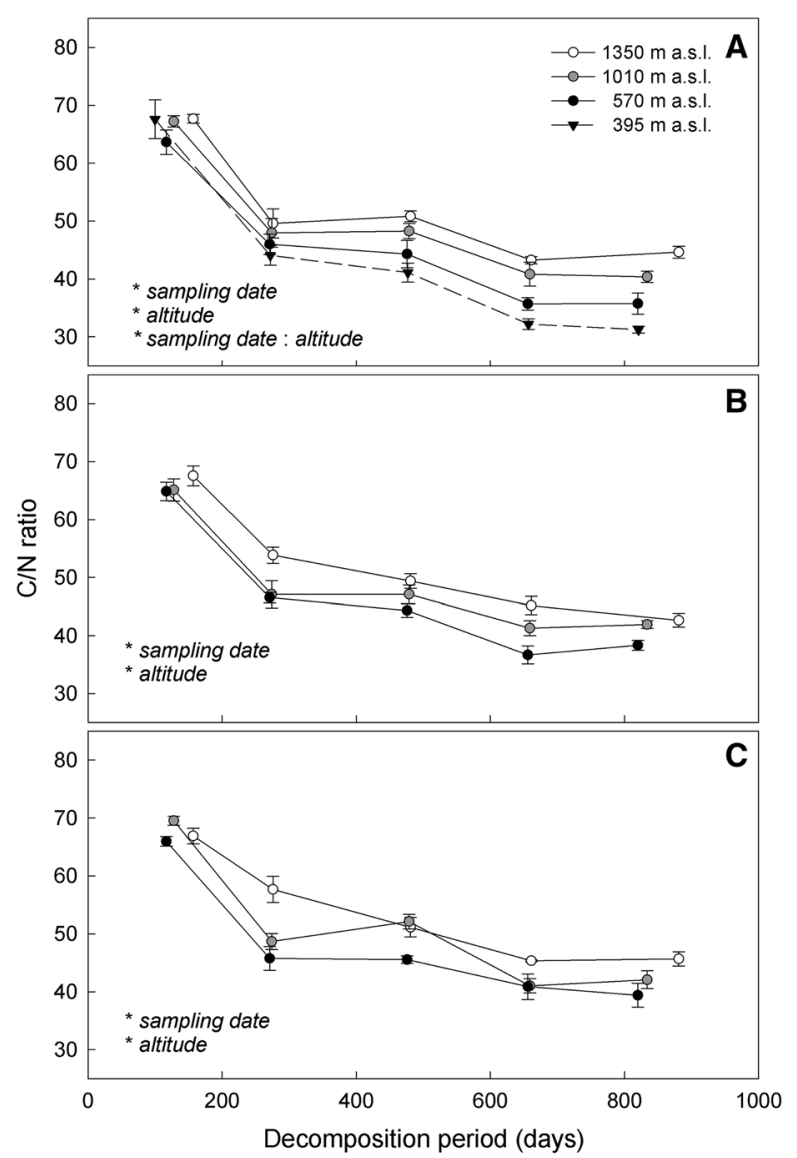

Figure 5. Dynamics of leaf litter $\mathrm{C} / \mathrm{N}$ ratio during the decomposition period in mesocosms with turfs from: A unwooded pasture, B sparsely wooded pasture, and $\mathbf{C}$ densely wooded pasture land-use type. Presented are mean values and standard errors for five replicate mesocosms. At the lowest altitude only the unwooded pasture land use was considered. Asterisks indicate significant effects of the specified factors within each of the land-use types.

$\left(F_{1,46}=17.3, P<0.001\right)$, but did not affect the fungal ones.

\section{Discussion}

\section{Climate and Land-Use Driven Patterns in Litter Decomposition}

Decomposition rates over the two and a half year incubation period were within the range of most commonly reported $K$ values for leaf litter on a global basis, that is, 0.1 to 0.3 (Zhang and others 2008). Based on the type of land use, the mass loss from $F$. sylvatica litterbags showed distinct trajectories in its response to the climate along the altitude gradient. Only in the non-shaded UW mesocosms were the decay rates affected by the altitude

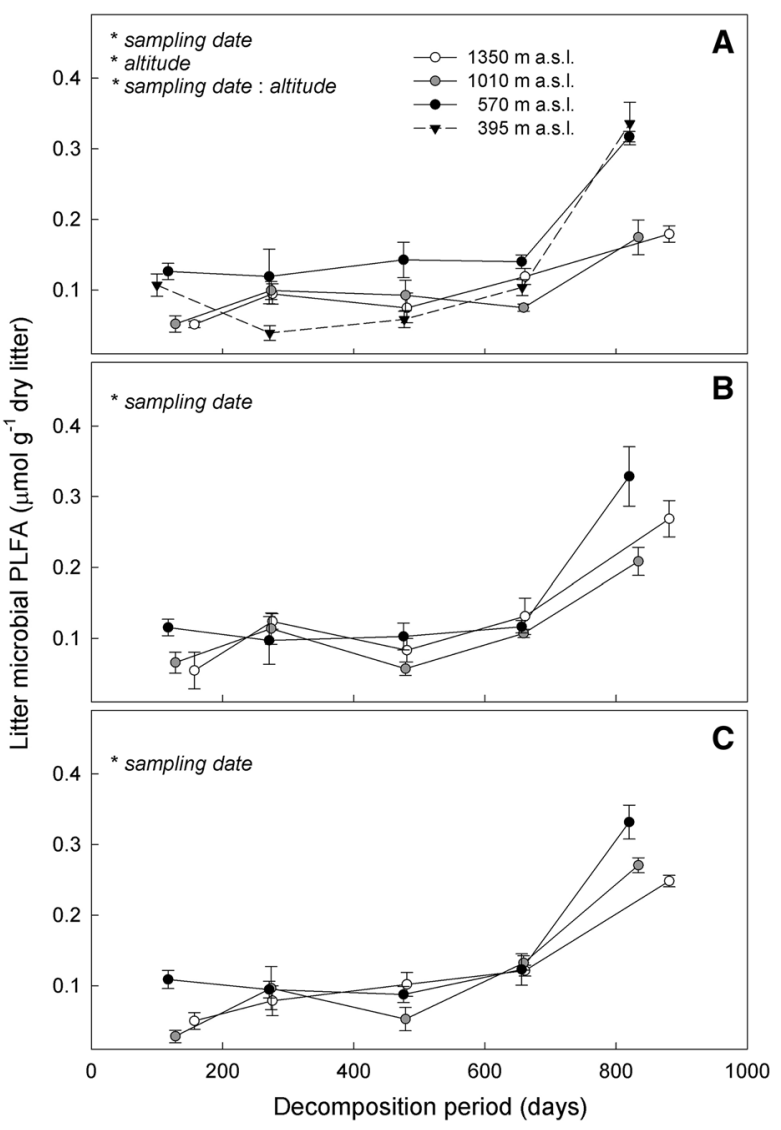

Figure 6. Microbial biomass on decomposing litter as represented by PLFA markers. Land-use types are: A unwooded pasture, B sparsely wooded pasture, and $\mathbf{C}$ densely wooded pasture. Presented are mean values and standard errors for five replicate mesocosms. At the lowest altitude only the unwooded pasture type was considered. Asterisks indicate significant effects of the specified factors within each of the land-use types.

treatment, with higher rates at higher altitude. Such a pattern was previously reported for altitudinal transects across vegetation zones in North American (Murphy and others 1998) and European (Duboc and others 2012) mountains, but never, to our knowledge, for transplanted turfs, that is, under standardized soil conditions. Contrary to our hypothesis about a local optimum range for litter decomposition at mid-elevation, based on the offset between air temperature and precipitation along the climatic gradient, we observed either a clear linear relationship with altitude (UW land use), or no such at all (SW and DW land use). Indeed, our data provided evidence for a prevailing moisture limitation on the decomposition process. Temperature did not act as a constraint on litter decay at higher altitude, however, soil moisture exerted a strong control at lower 


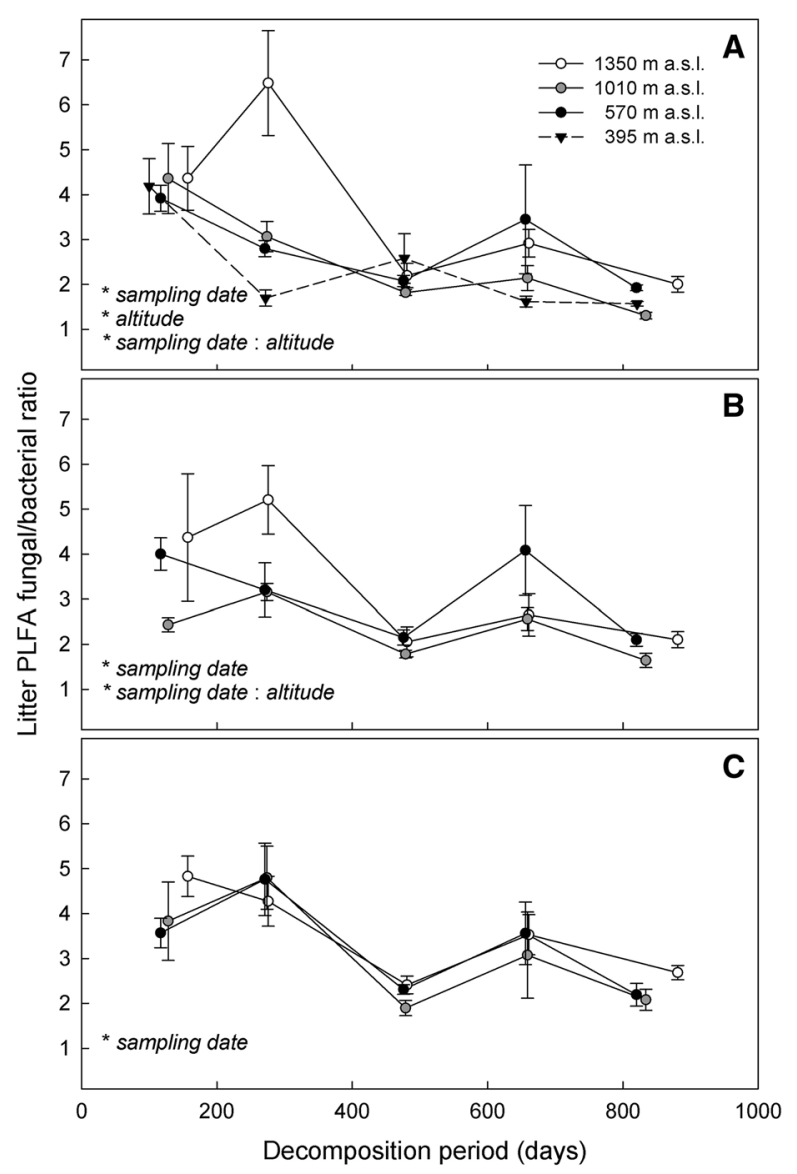

Figure 7. Ratio of fungal to bacterial PLFA markers in the litter bags. Land-use types are: A unwooded pasture, B sparsely wooded pasture, and C densely wooded pasture. Presented are mean values and standard errors for five replicate mesocosms. At the lowest altitude only the unwooded pasture type is considered. Asterisks indicate significant effects of the specified factors within each of the land-use types.

altitude. Indeed, both litter mass loss and soil moisture decreased significantly with warmer and drier climate at lower altitude within the UW mesocosms. In contrast, within the two shaded land-use types (SW and DW), where no change in decomposition rates was detected in relation to altitude, temperature was consistently warmer at lower altitudes, but soil moisture experienced an idiosyncratic seasonal pattern, with no consistent altitudinal gradient over the entire incubation period. These results suggest a strong point about the role of soil moisture as a driving factor of leaf litter decomposition and furthermore neatly demonstrate the importance of vegetation type (that is, land use, canopy cover, and so on) for modulating evapotranspiration and subsequently decomposition rates (see Aerts 2006). A relevant process taking place on the surface of the mesocosms is the net difference in radiative heating among the three land-use types. Due to their shading, each of the two "wooded" treatments experienced, on average, cooler temperatures than the UW one. Hence, taking into account the intensified evapotranspiration at warmer air and/or soil temperatures (Seneviratne and others 2006), UW mesocosms were much more prone to soil moisture limitation during persistent warm and dry periods. At the landscape scale, such a dichotomy in the response of grasslands and forests to heat waves was demonstrated too (Teuling and others 2010), providing evidence for a more conservative use of water by forests, which preserves soil moisture in the long term and prevents excessive heating due to drought.

Our five biannual samplings allowed us to study the intra-seasonal decomposition pattern and the observed steady decay rates provided evidence for comparable mass loss across seasons. On the one hand, this agrees with previous studies demonstrating substantial mass loss rates during the winter season (Sjögersten and Wookey 2004; Baptist and others 2010; Saccone and others 2013). On the other hand, it is in contrast to the stipulated model of faster and slower stages of litter decomposition based on a decreasing litter quality over the course of the decomposition process (Couteaux and others 1995). This could be tentatively explained by the principle that the early stages of decay are substrate quality driven and the later stages are microbial community composition driven (Bray and others 2012), such that the interplay between those and the seasonal change in climate and microbial structure (see Bardgett and others 2005; and the discussion below) has resulted in the observed steady decomposition rate over the entire incubation period.

\section{Microbial Community Shifts in Relation to Litter Chemistry and Decomposition Along the Altitudinal Gradient}

Plant litter chemistry changed substantially over the course of time, with litter $\mathrm{C} / \mathrm{N}$ ratio decreasing both as decomposition progressed and in response to the altitudinal treatment. The observed change in $\mathrm{C} / \mathrm{N}$ ratio was exclusively due to an increase in $\mathrm{N}$ concentration in the litter, following microbial immobilization of nitrogen from the soil (Melillo and others 1982; Parton and others 2007). Because litter quality and $\mathrm{N}$ content, in particular, have a dominant role in determining decomposition rates globally (Cornwell and others 2008), recalcitrant 
litter types (such as F. sylvatica) require that allochthonous $\mathrm{N}$ is brought up by microbes to access the C in the litter (Rutigliano and others 1998). In this study, the process occurred after 1 year of incubation, during the first plant growing season and not during the preceding winter (see Figures 5, Al), indicating a prior limitation in $\mathrm{N}$-availability and/or limited colonization by microbial decomposers (see also Figure 6) during the first winter. Furthermore, the disproportional decrease in litter $\mathrm{C} / \mathrm{N}$ within mesocosms at lower altitudes could be due to a general increase in $\mathrm{N}$-availability resulting from warmer soil temperatures. Indeed, we found a concomitant increase of $\mathrm{N}$-mineralization rates and leaching of $\mathrm{N}$ into the soil solution at lower altitudes (Supplementary Material, Table Al) - a trend which has been previously established for both altitudinal gradients (Zhang and others 2012) and globally in warming experiments (Bai and others 2013). The land-use pattern of lower $\mathrm{C} / \mathrm{N}$ ratios in litterbags incubated in UW mesocosms could be further attributed to the synergistic effect of extant labile grassland litter (that is, lower soil organic matter $\mathrm{C} / \mathrm{N}$ ratio, Table 1) on the decomposition rates of $F$. sylvatica, allowing the transfer of $\mathrm{N}$ between the two (see Schimel and Hättenschwiler 2007).

Alongside the decrease in litter $\mathrm{C} / \mathrm{N}$ stoichiometry, a change in microbial community structure took place, resulting in a matching decrease in fungal/bacterial ratios in the litter bags during the period of decomposition. In line with the decrease in fungal/bacterial ratios reported with increased management intensity, increased nutrient availability, and early successional stage (van der Heijden and others 2008), we interpret our results for a decrease in fungal/bacterial ratio at lower altitude (especially in the UW mesocosms) as an alteration of the nutrient cycle. This follows from the general concept for an increasing importance of bacteria in ecosystems experiencing a faster nutrient cycle (Wardle and others 2004). Hence it is very likely that the observed increase in both $\mathrm{N}$-mineralization rates and concentration of organic and inorganic forms of $\mathrm{N}$ in the soil solution at lower altitude caused the shift toward a microbial community rich in bacteria.

Furthermore, the observed temporal dynamics in fungal/bacterial ratio could be attributed to the change in microbial community structure with respect to seasonality, as reported by Schmidt and Lipson (2004). The oscillating pattern, clearly seen in the two wooded pasture land-use types (Figure 7) can be explained by the principle that senesced litter in autumn is colonized by fungi responsible for its degradation over winter, and the subsequent increase in $\mathrm{N}$-availability in the soil solution in spring results in a substantial immobilization by bacteria. Our results suggest that this process in the soil microbial community can be severely disrupted by altered climate as seen in the UW land use, but also that in wooded pastures characterized by a more buffered microclimate and edaphic conditions the decomposer communities experience a much lower impact from climatic perturbation.

\section{Conclusions}

The spatial and temporal continuum of leaf litter decomposition rates presented with this experiment demonstrated the potential of climate gradient studies for the detection of causal relationships between ecosystem processes and climate variability. The linearity in the response of litter decomposition within UW pastures to climate change revealed the hierarchical controlling role of soil moisture on this process. Surprisingly, we did not find evidence for temperature limitation on this process. The observed land-use driven response of litter decomposition to climate has potentially important implications for carbon cycling under climate change. Besides exerting a direct microclimatic effect on litter decomposition, wooded pastures also supported a community of microbial decomposers resistant to climate change perturbation and sustained its functional composition and activity.

\section{ACKNOWLEDGMENTS}

This work was supported by the CCES (Competence Center Environment and Sustainability of the ETH Domain, Switzerland) as part of the Mountland project. Arboretum National d'Aubonne, Commune of St-George (VD), Parc Jurassien Vaudois, and Fondation Les Bois Chamblard provided logistics and infrastructure support. We are grateful to Laurent Grasset for introducing us to the PLFA technique.

\section{REFERENCES}

Aerts R. 2006. The freezer defrosting: global warming and litter decomposition rates in cold biomes. J Ecol 94:713-24.

Allison SD, Lu Y, Weihe C, Goulden ML, Martiny AC, Treseder KK, Martiny JBH. 2013. Microbial abundance and composition influence litter decomposition response to environmental change. Ecology 94:714-25.

Andersen R, Grasset L, Thormann MN, Rochefort L, Francez AJ. 2010. Changes in microbial community structure and function following Sphagnum peatland restoration. Soil Biol Biochem 42:291-301. 
Bai E, Li SL, Xu WH, Li W, Dai WW, Jiang P. 2013. A metaanalysis of experimental warming effects on terrestrial nitrogen pools and dynamics. New Phytol 199:431-40.

Baptist F, Yoccoz N, Choler P. 2010. Direct and indirect control by snow cover over decomposition in alpine tundra along a snowmelt gradient. Plant Soil 328:397-410.

Bardgett RD, Bowman WD, Kaufmann R, Schmidt SK. 2005. A temporal approach to linking aboveground and belowground ecology. Trends Ecol Evol 20:634-41.

Bardgett RD, Hobbs PJ, Frostegard A. 1996. Changes in soil fungal:bacterial biomass ratios following reductions in the intensity of management of an upland grassland. Biol Fertil Soils 22:261-4.

Bardgett RD, Manning P, Morrien E, De Vries FT. 2013. Hierarchical responses of plant-soil interactions to climate change: consequences for the global carbon cycle. J Ecol 101:334-43.

Beier C, Beierkuhnlein C, Wohlgemuth T, Penuelas J, Emmett B, Korner C, de Boeck HJ, Christensen JH, Leuzinger S, Janssens IA, Hansen K. 2012. Precipitation manipulation experiments-challenges and recommendations for the future. Ecol Lett 15:899-911.

Bray SR, Kitajima K, Mack MC. 2012. Temporal dynamics of microbial communities on decomposing leaf litter of 10 plant species in relation to decomposition rate. Soil Biol Biochem 49:30-7.

Chapin FS, Matson PA, Mooney HA. 2002. Terrestrial decomposition. In: Chapin FSIII, Matson PA, Mooney HA, Eds. Principles of Terrestrial Ecosystem Ecology. New York: Springer. p 151.

Cornelissen JHC. 1996. An experimental comparison of leaf decomposition rates in a wide range of temperate plant species and types. J Ecol 84:573-82.

Cornelissen JHC, van Bodegom PM, Aerts R, Callaghan TV, van Logtestijn RSP, Alatalo J, Chapin FS, Gerdol R, Gudmundsson J, Gwynn-Jones D, Hartley AE, Hik DS, Hofgaard A, Jonsdottir IS, Karlsson S, Klein JA, Laundre J, Magnusson B, Michelsen A, Molau U, Onipchenko VG, Quested HM, Sandvik SM, Schmidt IK, Shaver GR, Solheim B, Soudzilovskaia NA, Stenstrom A, Tolvanen A, Totland O, Wada N, Welker JM, Zhao XQ. 2007. Global negative vegetation feedback to climate warming responses of leaf litter decomposition rates in cold biomes. Ecol Lett 10:619-27.

Cornwell WK, Cornelissen JHC, Amatangelo K, Dorrepaal E, Eviner VT, Godoy O, Hobbie SE, Hoorens B, Kurokawa H, Perez-Harguindeguy N, Quested HM, Santiago LS, Wardle DA, Wright IJ, Aerts R, Allison SD, van Bodegom P, Brovkin V, Chatain A, Callaghan TV, Diaz S, Garnier E, Gurvich DE, Kazakou E, Klein JA, Read J, Reich PB, Soudzilovskaia NA, Vaieretti MV, Westoby M. 2008. Plant species traits are the predominant control on litter decomposition rates within biomes worldwide. Ecol Lett 1 1:1065-71.

Cottingham KL, Lennon JT, Brown BL. 2005. Knowing when to draw the line: designing more informative ecological experiments. Front Ecol Environ 3:145-52.

Couteaux MM, Bottner P, Berg B. 1995. Litter decomposition, climate and litter quality. Trends Ecol Evol 10:63-6.

Crossley DA, Hoglund MP. 1962. Litter-bag method for study of microarthropods inhabiting leaf litter. Ecology 43:571-3.

de Vries FT, Liiri ME, Bjornlund L, Bowker MA, Christensen S, Setala HM, Bardgett RD. 2012. Land use alters the resistance and resilience of soil food webs to drought. Nat Clim Change $2: 276-80$.
Duboc O, Zehetner F, Djukic I, Tatzber M, Berger TW, Gerzabek MH. 2012. Decomposition of European beech and Black pine foliar litter along an Alpine elevation gradient: mass loss and molecular characteristics. Geoderma 189:522-31.

Engqvist L. 2005. The mistreatment of covariate interaction terms in linear model analyses of behavioural and evolutionary ecology studies. Anim Behav 70:967-71.

Gavazov K, Spiegelberger T, Buttler A. 2014. Transplantation of subalpine wood-pasture turfs along a natural climatic gradient reveals lower resistance of unwooded pastures to climate change compared to wooded ones. Oecologia 174:1425-35.

Gavazov KS. 2010. Dynamics of alpine plant litter decomposition in a changing climate. Plant Soil 337:19-32.

Green BF, Tukey JW. 1960. Complex analyses of variance: general problems. Psychometrika 25:127-52.

Houghton RA. 2007. Balancing the global carbon budget. Ann Rev Earth Planet Sci 35:313-47.

Körner C. 2003. Alpine plant life: functional plant ecology of high mountain ecosystems. Berlin, Heidelberg, New York: Springer.

Körner C. 2007. The use of 'altitude' in ecological research. Trends Ecol Evol 22:569-74.

Melillo JM, Aber JD, Muratore JF. 1982. Nitrogen an lignin control of hardwood leaf litter decomposition dynamics. Ecology 63:621-6.

Mueller B, Seneviratne SI. 2012. Hot days induced by precipitation deficits at the global scale. Proc Nat Acad Sci USA 109:12398-403.

Murphy KL, Klopatek JM, Klopatek CC. 1998. The effects of litter quality and climate on decomposition along an elevational gradient. Ecol Appl 8:1061-71.

Nogues-Bravo D, Araujo MB, Errea MP, Martinez-Rica JP. 2007. Exposure of global mountain systems to climate warming during the 21st century. Glob Environ Change Hum Policy Dimens 17:420-8.

Olson JS. 1963. Energy-storage and balance of producers and decomposers in ecological-systems. Ecology 44:322-31.

Parton W, Silver WL, Burke IC, Grassens L, Harmon ME, Currie WS, King JY, Adair EC, Brandt LA, Hart SC, Fasth B. 2007. Global-scale similarities in nitrogen release patterns during long-term decomposition. Science 315:361-4.

Pinheiro J, Bates D, DebRoy S, Sarkar D, The R Development Core Team. 2012. nlme: linear and nonlinear mixed effects models. $\mathrm{R}$ package version 3.1-104.

Robinson CH. 2002. Controls on decomposition and soil nitrogen availability at high latitudes. Plant Soil 242:65-81.

Rutigliano FA, Alfani A, Bellini L, De Santo AV. 1998. Nutrient dynamics in decaying leaves of Fagus sylvatica L. and needles of Abies alba Mill. Biol Fertil Soils 27:119-26.

Saccone P, Morin S, Baptist F, Bonneville JM, Colace MP, Domine F, Faure M, Geremia R, Lochet J, Poly F, Lavorel S, Clement JC. 2013. The effects of snowpack properties and plant strategies on litter decomposition during winter in subalpine meadows. Plant Soil 363:215-29.

Schimel JP, Hättenschwiler S. 2007. Nitrogen transfer between decomposing leaves of different $\mathrm{N}$ status. Soil Biol Biochem 39:1428-36.

Schmidt SK, Lipson DA. 2004. Microbial growth under the snow: implications for nutrient and allelochemical availability in temperate soils. Plant Soil 259:1-7. 
Seneviratne SI, Luthi D, Litschi M, Schar C. 2006. Land-atmosphere coupling and climate change in Europe. Nature 443:205-9.

Sjögersten S, Wookey PA. 2004. Decomposition of mountain birch leaf litter at the forest-tundra ecotone in the Fennoscandian mountains in relation to climate and soil conditions. Plant Soil 262:215-27.

Solomon S, Qin D, Manning M, Chen Z, Marquis M, Averyt KB, Tignor M, Miller HL. 2007. Climate change 2007: the physical science basis. Contribution of Working Group I to the Fourth Assessment Report of the Intergovernmental Panel on Climate Change. Cambridge, UK and New York, USA: Cambridge University Press.

Steinweg JM, Dukes JS, Wallensteine MD. 2012. Modeling the effects of temperature and moisture on soil enzyme activity: linking laboratory assays to continuous field data. Soil Biol Biochem 55:85-92.

Teuling AJ, Seneviratne SI, Stockli R, Reichstein M, Moors E, Ciais P, Luyssaert S, van den Hurk B, Ammann C, Bernhofer C, Dellwik E, Gianelle D, Gielen B, Grunwald T, Klumpp K, Montagnani L, Moureaux C, Sottocornola M, Wohlfahrt G. 2010. Contrasting response of European forest and grassland energy exchange to heatwaves. Nat Geosci 3:722-7.

van der Heijden MGA, Bardgett RD, van Straalen NM. 2008. The unseen majority: soil microbes as drivers of plant diversity and productivity in terrestrial ecosystems. Ecol Lett 11:296-310.
Wardle DA, Bardgett RD, Klironomos JN, Setala H, van der Putten WH, Wall DH. 2004. Ecological linkages between aboveground and belowground biota. Science 304:1629-33.

Weber P, Pluess AR, Mühlethaler U. 2010. Resources of beech in Switzerland. In: Frýdl J, Novotný P, Fennessy J, von Wühlisch G, Eds. Genetic resources of beech in Europe. Results of COST E52, Vol. 25p 248-55. Special issue of Communicationes Instituti Forestalis Bohemicae

White DC, Davis WM, Nickels JS, King JD, Bobbie RJ. 1979. Determination of the sedimentary microbial biomass by extractible lipid phosphate. Oecologia 40:51-62.

Wilkinson SC, Anderson JM, Scardelis SP, Tisiafouli M, Taylor A, Wolters V. 2002. PLFA profiles of microbial communities in decomposing conifer litters subject to moisture stress. Soil Biol Biochem 34:189-200.

Zhang D, Hui D, Luo Y, Zhou G. 2008. Rates of litter decomposition in terrestrial ecosystems: global patterns and controlling factors. J Plant Ecol 1:85-93.

Zhang SH, Chen DD, Sun DS, Wang XT, Smith JL, Du GZ. 2012. Impacts of altitude and position on the rates of soil nitrogen mineralization and nitrification in alpine meadows on the eastern Qinghai-Tibetan Plateau, China. Biol Fertil Soils 48:393-400. 